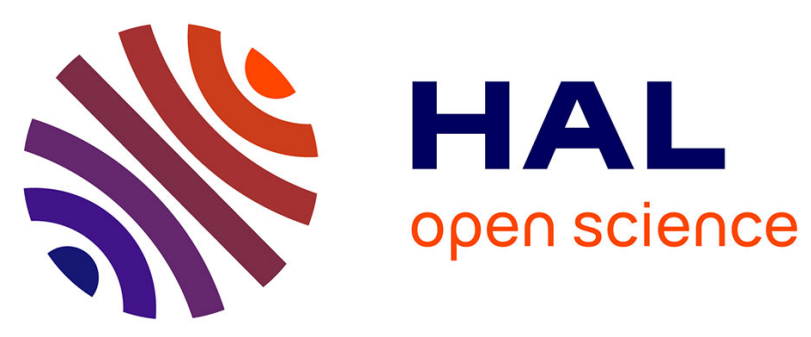

\title{
X-ray Diffraction, NMR Studies, and DFT Calculations of the Room and High Temperature Structures of Rubidium Cryolite, Rb 3 AlF 6
}

\author{
Aydar Rakhmatullin, František Šimko, Emmanuel Véron, Mathieu Allix, \\ Charlotte Martineau-Corcos, Andy Fitch, Franck Fayon, Roman A \\ Shakhovoy, Kirill Okhotnikov, Vincent Sarou-Kanian, et al.
}

\section{To cite this version:}

Aydar Rakhmatullin, František Šimko, Emmanuel Véron, Mathieu Allix, Charlotte Martineau-Corcos, et al.. X-ray Diffraction, NMR Studies, and DFT Calculations of the Room and High Temperature Structures of Rubidium Cryolite, Rb 3 AlF 6. Inorganic Chemistry, 2020, 59 (9), pp.6308-6318. 10.1021/acs.inorgchem.0c00415 . hal-03010638

\section{HAL Id: hal-03010638 \\ https://hal.science/hal-03010638}

Submitted on 17 Nov 2020

HAL is a multi-disciplinary open access archive for the deposit and dissemination of scientific research documents, whether they are published or not. The documents may come from teaching and research institutions in France or abroad, or from public or private research centers.
L'archive ouverte pluridisciplinaire HAL, est destinée au dépôt et à la diffusion de documents scientifiques de niveau recherche, publiés ou non, émanant des établissements d'enseignement et de recherche français ou étrangers, des laboratoires publics ou privés. 


\title{
X-ray diffraction, NMR studies, and DFT calculations of the room and high temperature structures of rubidium cryolite, $R_{3} \mathrm{AlF}_{6}$
}

\author{
Aydar Rakhmatullin ${ }^{*, \dagger}$, František Šimko, ${ }^{*,+}$, Emmanuel Véron ${ }^{\dagger}$, Mathieu Allix ${ }^{\dagger}$, Charlotte Marti- \\ neau-Corcos ${ }^{\dagger}, \S$, Andy Fitch"l, Franck Fayon ${ }^{\dagger}$, Roman A. Shakhovoy ${ }^{\dagger}$, Kirill Okhotnikov ${ }^{\dagger}$, Vincent \\ Sarou-Kanian ${ }^{\dagger}$, Michal Korenko ${ }^{\ddagger}$, Z Zuzana Netriová $^{\ddagger}$, Ilja B.Polovov ${ }^{?}$, and Catherine Bessada ${ }^{\dagger}$
}

\author{
† Conditions Extrêmes et Matériaux: Haute Température et Irradiation, CEMHTI, UPR 3079 -CNRS Univ. Orléans \\ 45071, Orléans, France. \\ ₹ Institute of Inorganic Chemistry, Slovak Academy of Sciences, 84536 Bratislava, Slovakia. \\ ' Centre of Excellence for advanced Materials Application - CEMEA, Slovak Academy of Sciences, Dúbravská cesta \\ 5807/9, 84511 Bratislava, Slovakia \\ $\S$ Université de Versailles Saint-Quentin en Yvelines, 45 Avenue des Etats-Unis, 78035 Versailles Cedex, France \\ "ID22, ESRF, Grenoble, France \\ ? Department of Rare Metals and Nanomaterials, Institute of Physics and Technology Ural Federal University, Eka- \\ terinburg, Russia
}

KEYWORDS rubidium cryolite, $\mathrm{Rb}_{3} \mathrm{AlF}_{6}$, phase transitions, solid-state NMR, X-ray powder diffraction, CASTEP

\begin{abstract}
A crystallographic approach incorporating multinuclear high field solid state NMR (SSNMR), X-ray structure determinations, TEM observation, and density functional theory (DFT) was used to characterize two polymorphs of rubidium cryolite, $\mathrm{Rb}_{3} \mathrm{AlF}_{6}$. The room temperature phase was found to be ordered and crystallizes in the $F d d d\left(\mathrm{n}^{\circ} 7 \mathrm{o}\right)$ space group with $a=37.26491(1) \AA ̊, b=12.45405(4) \AA ̊, c=17.68341(6) \AA$. Comparison of NMR measurements and computational results revealed the dynamic rotations of the $\mathrm{AlF}_{6}$ octahedra. Using in-situ variable temperature MAS NMR measurements, the chemical exchange between rubidium sites was observed. The $\beta$-phase, i.e. high temperature polymorph, adopts the ideal cubic double-perovskite structure, space group $F m \overline{3} m$, with a $=8.9930(2) \AA$ at $600{ }^{\circ} \mathrm{C}$. Additionally, a series of polymorphs of $\mathrm{K}_{3} \mathrm{AlF}_{6}$ has been further characterized by high field high temperature SSNMR and DFT computation.
\end{abstract}

\section{INTRODUCTION}

The binary system $\mathrm{RbF}-\mathrm{AlF}_{3}$ belongs to a bigger family of cryolitic systems $\mathrm{MF}-\mathrm{AlF}_{3}(\mathrm{M}=\mathrm{Li}, \mathrm{Na}, \mathrm{K}, \mathrm{Rb}, \mathrm{Cs}, \mathrm{Fr})$. While one member of this family, molten sodium cryolite (NaF$\mathrm{AlF}_{3}$ ), is the main constituent of the electrolyte for the industrial production of aluminum worldwide, the other members of that cryolitic family $(\mathrm{Li}, \mathrm{K}, \mathrm{Rb})$ could have also been considered because of their role as the constituents for the new "low-melting" electrolytes in electrometallurgy. ${ }^{1}$

The structure of rubidium cryolite and the solubility of the alumina, with consequent formation of the electroactive species, is the principal task for the potential utilization of rubidium cryolite in the aluminium electrowinning. Little information is however available about $\mathrm{Rb}_{3} \mathrm{AlF}_{6}$ in open lit- erature compared to, for example its analogues lithium, sodium and potassium cryolite $\left(\mathrm{Li}_{3} \mathrm{AlF}_{6},{ }^{2,3} \mathrm{Na}_{3} \mathrm{AlF}_{6},{ }^{4-6}\right.$ and $\left.\mathrm{K}_{3} \mathrm{AlF}_{6},{ }^{7,8}\right)$. Holm analyzed the three cryolites $\mathrm{K}_{3} \mathrm{AlF}_{6}$, $\mathrm{Rb}_{3} \mathrm{AlF}_{6}$, and $\mathrm{Cs}_{3} \mathrm{AlF}_{6}$ by DTA and XRD methods. ${ }^{9}$ Cooling curves of pure $\mathrm{Rb}_{3} \mathrm{AlF}_{6}$ contained two exothermic peaks: liquid-solid phase transition at $920{ }^{\circ} \mathrm{C}$ and the other modification transition at $357^{\circ} \mathrm{C}$. XRD investigations showed that the room temperature form of $\mathrm{Rb}_{3} \mathrm{AlF}_{6}$ has tetragonal symmetry, while its high temperature modification is assumed to be face-centered cubic. Chen and Zhang ${ }^{10}$ studied the quenched samples of the system $\mathrm{RbF}-\mathrm{AlF}_{3}$ by DTA, DSC and XRD methods. Three compounds were identified: $\mathrm{Rb}_{3} \mathrm{AlF}_{6}, \mathrm{RbAlF}_{4}$ and $\mathrm{RbAl}_{3} \mathrm{~F}_{7} . \mathrm{Rb}_{3} \mathrm{AlF}_{6}$ melts congruently at $878^{\circ} \mathrm{C}$ and its $\alpha \leftrightarrow \beta$ forms transformed reversibly at $340^{\circ} \mathrm{C}$. The crystal structures of both $\mathrm{Rb}_{3} \mathrm{AlF}_{6}$ modifications have not yet been completely described. 
The cryolite systems of alkali metals could also have other industrial applications. Recently, $\mathrm{Mn}^{4+}$ activated $\mathrm{K}_{3} \mathrm{AlF}_{6}$ was studied as a potential red phosphor for warm white light-emitting diodes." It shows an efficient luminous efficacy beyond $190 \mathrm{~lm} / \mathrm{W}$, along with an excellent color rendering index $(\mathrm{Ra}=84)$ and a lower correlated color temperature $(\mathrm{CCT}=3665 \mathrm{~K})$. These types of materials with improved performance that can be industrially produced at competitive cost are needed in different fields of industry and particle physics research. ${ }^{12,13}$

The specific crystal structural features, phase transitions, and related physical properties of the cryolite materials can be linked to structural similarity with a larger group of materials known as elpasolite halides (after the name of the mineral elpasolite, $\mathrm{K}_{2} \mathrm{NaAlF}_{6}$ ). These materials have a "mixed-cation" fluoride perovskite-type structure, in which the corner-sharing octahedral network is made up of alternating $\left(\mathrm{AlF}_{6}\right)$ and $\left(\mathrm{Na}(\mathrm{K}) \mathrm{F}_{6}\right)$ octahedra. Elpasolite $\left(\mathrm{A}_{2} \mathrm{BB}^{\prime} \mathrm{X}_{6}\right)$ and cryolite $\left(\mathrm{A}_{3} \mathrm{~B}^{\prime} \mathrm{X}_{6}\right)$ structure types derive from the perovskite by cationic ordering. Unlike simple $A_{B X}$ perovskites, where all octahedra are equivalent, in elpasolites (also known as ordered perovskites), there are two kinds of non-equivalent ionic groups $\mathrm{BX}_{6}$ and $\mathrm{B}^{\prime} \mathrm{X}_{6}$ alternating along the three four-fold cubic axes. Numerous elpasolite-like crystals are known to undergo structural phase transitions or to exist in distorted phases up to the melting temperature.

The structures of $\mathrm{K}_{3} \mathrm{AlF}_{6},{ }^{7,8} \mathrm{Sr}_{3} \mathrm{WO}_{6},{ }^{14} \mathrm{Rb}_{2} \mathrm{~K}(\mathrm{Cr}$ or $\mathrm{Ga}) \mathrm{F}_{6},{ }^{15}$ and $(\mathrm{K} \text { or } \mathrm{Rb})_{3} \mathrm{MoO}_{3} \mathrm{~F}_{3}{ }^{16}$ are a small part of the elpasolite or double perovskite type which show non-cooperative octahedral tilting (NCOT). In these phases, one of the octahedra is rotated by $\sim 45^{\circ}$ while the other remains untilted. Some of the elpasolite-type materials are suitable for scintilators, showing desirable isotropic optical and mechanical properties. ${ }^{17}$

In this paper, we will present a new example of the structure of $\mathrm{Rb}_{3} \mathrm{AlF}_{6}$ with non-cooperative octahedral tilting and the first complex NMR investigation of such compounds like $\mathrm{K}_{3} \mathrm{AlF}_{6}$ and $\mathrm{Rb}_{3} \mathrm{AlF}_{6}$. We will present a characterization of the structure of rubidium cryolites using $\mathrm{X}$-ray diffraction (XRD) and transmission electron microscopy (TEM). Both potassium and rubidium cryolites were characterized using various $1 \mathrm{D}$ and $2 \mathrm{D}$ solid state NMR techniques including in-situ HT MAS NMR. The interpretation of all experimental NMR results is significantly enhanced by the contribution of the first principle DFT calculations. We think that this computing approach was applied, for the first time, to such a complex structure.

\section{EXPERIMENTAL SECTION}

Preparation of pure compounds

$\mathrm{K}_{3} \mathrm{AlF}_{6}$

Potassium cryolite was prepared in a glovebox following the preparation detailed by Abakumov et al. ${ }^{7}$ and Šimko et al. ${ }^{18}$

$\mathrm{Rb}_{3} \mathrm{AlF}_{6}$ and $\mathrm{RbAlF}_{4}$
The synthesis protocol of rubidium cryolite was identical to that described in our previous work. ${ }^{19}$ Rubidium tetrafluoroaluminate was prepared by heating a stoichiometric mixture of $\mathrm{RbF}$ and $\mathrm{AlF}_{3}$. Two grams of mixture were mechanically homogenized in a glovebox under inert atmosphere (Ar - Messer, $99.999 \%$ purity), placed in a Pt crucible and heated in a tightly closed vertical resistance furnace with water-cooling from room temperature to $600{ }^{\circ} \mathrm{C}$, at a rate of $5^{\circ} \mathrm{C} / \mathrm{min}$. The mixture was held for 1 hour at 20 bars to avoid the dissociation reaction, and then cooled to room temperature. XRD patterns is shown in Supporting Information (Figure $\mathrm{S}$ ).

\section{Thermal analysis measurements}

The classical thermal analysis was performed as described by Šimko et al..$^{19}$ in a Pt crucible with a lid. The cooling rate was $1.4{ }^{\circ} \mathrm{C} / \mathrm{min}$. By using such a slower cooling rate in a larger quantity of sample (10 grams), it was possible to detect the real temperature of primary crystallization of $\mathrm{Rb}_{3} \mathrm{AlF}_{6}$. The slow cooling rate is essential for the thermal analysis of materials like $\mathrm{Rb}_{3} \mathrm{AlF}_{6}$ which often show extended thermal dissociation. ${ }^{20}$

\section{SSNMR measurements}

Room temperature solid-state NMR experiments were carried out on a Bruker Avance III NMR spectrometers operating at $9.4 \mathrm{~T}$ and $20.0 \mathrm{~T}$, using a $2.5 \mathrm{~mm}$ resonance probe at MAS frequency varying between 30 and $34 \mathrm{kHz}$. In addition, to enhance resolution in some of the ${ }^{19} \mathrm{~F}$ solid state NMR experiments, we used a $1.3 \mathrm{~mm}$ probe to be able to rotate samples up to $67 \mathrm{kHz}$. ${ }^{27} \mathrm{Al} \mathrm{NMR}$ spectra were acquired using a double frequency sweep (DFS) pulse due to a possibility of signal enhancement. The parameters of the dipolar ${ }^{87} \mathrm{Rb}^{-19} \mathrm{~F} \mathrm{HMQC}^{21,22}$ experiments were identical to our previous study. ${ }^{19}$

${ }^{87} \mathrm{Rb}$ MQMAS spectra were acquired with Z-filtering ${ }^{23}$ and hypercomplex (States) ${ }^{24}$ phase detection. A sweep width of $60 \mathrm{kHz}$ and $120 \mathrm{kHz}\left(4 v_{\mathrm{r}}\right)$ was used in the direct and indirect dimension, respectively. The optimized excitation and conversion pulse width was $4 \mu \mathrm{s}\left(\nu_{\mathrm{rf}}=62.5 \mathrm{kHz}\right)$ and $1.3 \mu \mathrm{s}$ $\left(v_{\mathrm{rf}}=192 \mathrm{kHz}\right)$, respectively. A repetition delay was $0.66 \mathrm{~s}$.

The in-situ high temperature NMR experiments were carried out on a Bruker Avance III HD NMR spectrometer operating at $17.6 \mathrm{~T}$ with resonance frequencies of $245.4 \mathrm{MHz}$ and $705.8 \mathrm{MHz}$ for ${ }^{87} \mathrm{Rb}$ and ${ }^{19} \mathrm{~F}$, respectively, employing a $7 \mathrm{~mm}$ Bruker laser MAS probe. The bottom-less MAS rotor is equipped with an inner container made from aluminium nitride (AIN) which carries the sample. Heating of the sample is achieved using a $200 \mathrm{~W}$ DILAS diode laser operating at $980 \mathrm{~nm}$. The laser beam is fed through an optical fiber into the probe, the fiber ending ca. $1 \mathrm{~cm}$ underneath the stator, and then directed to the AlN container. The ${ }^{27} \mathrm{Al}$ background signal is very large hence no ${ }^{27} \mathrm{Al}$ NMR measurements were recorded. In all in-situ HT experiments, the MAS frequency was $5000 \mathrm{~Hz}$. Because of the broad NMR patterns of ${ }^{19} \mathrm{~F}$ and ${ }^{87} \mathrm{Rb}$ resulting from large chemical shift anisotropy and low MAS rate, two-dimensional (2D) NMR techniques, MATPASS ${ }^{25}$ and QMATPASS, ${ }^{26}$ for ${ }^{19} \mathrm{~F}$ and ${ }^{87} \mathrm{Rb}$ respectively that able to separate the isotropic and the anisotropic chemical shifts in two different dimensions were 
employed, as ideal approach to study our samples at very high temperature. They yield high-resolution NMR isotropic peaks free of CSA-related broadening in one dimension and the corresponding anisotropic powder sideband pattern for each isotropic peak, in the second dimension. The separation of the side bands has been carried out with $5-\pi$ MATPASS experiment for ${ }^{19} \mathrm{~F}$ and $9-\pi$ QMATPASS pulse sequence for ${ }^{87} \mathrm{Rb}$. Duration of the $\pi$ pulse was $15.5 \mu \mathrm{s}$ for ${ }^{19} \mathrm{~F}$ and $10 \mu \mathrm{s}$ for ${ }^{87} \mathrm{Rb}$. To avoid the time conflict caused by the finite length of the pulse, even $\pi$ pulses were placed at $2 / 3$ and $4 / 3$ of the rotor period in case of MATPASS and $2 / 5,4 / 5,6 / 5$, and $8 / 5$ of the rotor period in case of QMAT, such that the whole pulse sequences spanned almost $3 \tau_{\mathrm{r}}$ at first $t_{1}$ increment and $2 \tau_{\mathrm{r}}$ at the last one. 12-step and 20-step cogwheel phase cycling ${ }^{27}$ was used to select the alternating coherence transfer pathway in MATPASS and QMATPASS experiments, respectively. Each $t_{1}$ increment was acquired at 48 transients for ${ }^{19} \mathrm{~F}$ and at 1000 scans for ${ }^{87} \mathrm{Rb}$.

${ }^{19} \mathrm{~F},{ }^{27} \mathrm{Al}$, and ${ }^{87} \mathrm{Rb}$ chemical shifts are referenced to $\mathrm{CFCl}_{3}, 1$ $\mathrm{M} \mathrm{Al}\left(\mathrm{NO}_{3}\right)_{3}$, and o.o1 $\mathrm{M} \mathrm{RbNO}_{3}$, respectively. The NMR parameters (chemical shifts, chemical shift anisotropies, asymmetry parameters, line widths, and quadrupolar parameters) were fitted for several different rotor frequencies and for two magnetic fields to the experimental spectra by means of the DMfit program. ${ }^{28}$

Temperature calibration

Temperature measurement in the case of laser heating cannot be performed directly; hence, an indirect calibration of the temperature was used. It is obvious that heating the container from only one side leads to a considerable temperature gradient in the sample. To reduce the value of the temperature gradient, a small amount of the powder was used (about $20 \mathrm{mg}$ ). The temperature calibration was performed using several reference compounds $\mathrm{K}_{3} \mathrm{AlF}_{6}\left({ }^{19} \mathrm{~F}\right.$ spectra), ${ }^{8}$, this paper $\mathrm{Rb}_{3} \mathrm{AlF}_{6}$ ( ${ }^{19} \mathrm{~F}$ and ${ }^{87} \mathrm{Rb}$ ), ${ }^{9}$, this paper $\mathrm{Na}_{2} \mathrm{SiF}_{6}$ $\left({ }^{23} \mathrm{Na}\right),{ }^{29}$ and $\mathrm{CuI}, \mathrm{CuBr}\left({ }^{6} \mathrm{Cu}\right),{ }^{30}$ whose phase transition temperature is well defined. The laser power exhibits a temperature dependence given by Shakhovoy et al. ${ }^{11} P=$ $a T^{4}+b T-c$, where $a, b, c$ are constants, $P$ is a percentage of the maximum laser power controlled by the experimenter. In addition, the calibration was double checked by employing the temperature dependence of the ${ }^{79} \mathrm{Br}$ MAS NMR signal of $\mathrm{KBr}: 3^{2} T=-40 \times \delta_{\text {iso }}+R T$. In the temperature range $200-$ $500{ }^{\circ} \mathrm{C}$, the agreement between the two methods of calibration is highly satisfying (Figure $\mathrm{S}_{2}$ ).

First-Principles Calculations

Calculations of NMR parameters were identical to our previous study ${ }^{18}$ and the computational details are presented in the Supporting Information. Linear regressions led to the following relationships for ${ }^{19} \mathrm{~F}: \delta_{\text {iso }}(\mathrm{ppm})=-0.795 \times \sigma_{\text {iso }}+$ 89.444 .33

Electron diffraction

Electron diffraction patterns were collected on a Philips CMzo microscope fitted with an Oxford energy dispersive spectrometry (EDS) analyzer. In order to avoid rapid deterioration of the samples under the electron beam, a nitrogen-cooled sample holder was used.
Synchrotron Powder Diffraction

Synchrotron powder diffraction measurements were performed at the ESRF beamline ID22 (Grenoble, France) operating at the wavelength $0.32623 \AA$. The measurements were performed at several temperatures using a hot-air blower sensor while heating the $\mathrm{Rb}_{3} \mathrm{AlF}_{6}$ sample from room temperature up to $600{ }^{\circ} \mathrm{C}$. A 12-min waiting time was used at each temperature step in order to ensure thermal equilibration, then powder synchrotron data was collected over the $0.5-48^{\circ} 2 \theta$ with a $0.002^{\circ}$ step size. Polycrystalline powder samples were sealed in $0.5 \mathrm{~mm}$ diameter borosilicate capillaries, which were rotated in order to reduce potential texture effects.

\section{RESULTS}

$\mathrm{M}_{3} \mathrm{AlF}_{6}(\mathrm{M}=\mathrm{Li}, \mathrm{Na}, \mathrm{K})$ compositions generally belong to congruently melting compounds with one simple endothermic signature. During cooling, $\mathrm{Li}_{3} \mathrm{AlF}_{6}$ shows an endothermic peak corresponding to crystallization at $782-785$ ${ }^{\circ} \mathrm{C}, 34 \mathrm{Na}_{3} \mathrm{AlF}_{6}$ at $1011{ }^{\circ} \mathrm{C},{ }^{1}$ and $\mathrm{K}_{3} \mathrm{AlF}_{6}$ at $974{ }^{\circ} \mathrm{C} .{ }^{9}$ The thermal endothermic effect of $\mathrm{Rb}_{3} \mathrm{AlF}_{6}$ was in this work obtained from the melt by thermal analysis at $920^{\circ} \mathrm{C}$ (Figure $\mathrm{S}_{3}$ ). The whole thermal cooling curve also contains other endothermic delay located at $346^{\circ} \mathrm{C}$. This delay corresponds to the polymorphic solid transition of the high temperature $\beta$ modification of $\mathrm{Rb}_{3} \mathrm{AlF}_{6}$ to the low temperature of $\alpha$ $\mathrm{Rb}_{3} \mathrm{AlF}_{6}$ (Figure $\mathrm{S}_{3}$, right). This is in good agreement with values previously reported by Holm, ${ }^{9}$ Chen and Zhang. ${ }^{10}$ The similar behavior of solid state crystal transformation is not unusual, even in between others $\mathrm{M}_{3} \mathrm{AlF}_{6}$ compounds. This behavior relates to the phase transition from hightemperature, high-symmetry modifications to a low-temperature, low symmetry forms. $\mathrm{Li}_{3} \mathrm{AlF}_{6}$, for example, forms four modifications: $\delta$-, $\gamma$-, $\beta$-, and $\alpha$-forms. High-temperature $\delta$-form transforms to $\gamma$-form at $597^{\circ} \mathrm{C}$ and $\gamma \leftrightarrow \beta$ transformation occurs at $510{ }^{\circ} \mathrm{C} .^{2}$ Last $\beta \leftrightarrow \alpha$ equilibrium occurs at $210^{\circ} \mathrm{C} .{ }^{3}$ On the other hand, $\mathrm{Na}_{3} \mathrm{AlF}_{6}$ forms only one solidsolid transformation. The cubic high-temperature $\beta$ $\mathrm{Na}_{3} \mathrm{AlF}_{6}$ is at $563{ }^{\circ} \mathrm{C}$ in equilibrium with the low-temperature monoclinic $\alpha-\mathrm{Na}_{3} \mathrm{AlF}_{6} .^{5}$ Three phase transitions of $\mathrm{K}_{3} \mathrm{AlF}_{6}$ are identified at $306{ }^{\circ} \mathrm{C}, 153^{\circ} \mathrm{C}$, and $132{ }^{\circ} \mathrm{C}$. The hightemperature $\delta$-phase is at $306^{\circ} \mathrm{C}$ in equilibrium with orthorhombic $\gamma$-phase. $\gamma$-phase forms at $153{ }^{\circ} \mathrm{C}$ an intermediate $\beta$-phase, which exists only in very narrow temperature intervals, and it is then being transformed at $132^{\circ} \mathrm{C}$ to a stable monoclinic $\alpha$-phase. ${ }^{8}$

$\alpha-\mathrm{Rb}_{3} \mathrm{AlF}_{6}$

Although the crystal structure of $\mathrm{Rb}_{3} \mathrm{AlF}_{6}$ has not been described up to now, unit cell parameters and symmetry were previously proposed based on X-ray powder diffraction data. ${ }^{10}$ Chen and Zhang suggested that the low temperature $\alpha$ form is orthorhombic with $a=7 \cdot 748(5) \AA, b=5 \cdot 365(3) \AA$, and $c=4.388(2) \AA$ while the high temperature $\beta$ one is cubic with $a=7.612(4) \AA$.

Diffraction data.

Using high-resolution synchrotron powder diffraction data, we first performed an auto-indexing analysis of the 
room temperature phase. The orthorhombic cell dimensions $a=37.2649 \AA, b=12.4541 \AA$ and $c=17.6834 \AA$ were determined with good reliability factors by indexing using Dicvol $^{40}$ and Treor ${ }^{41}$ programs and by analyzing the peak positions in the powder synchrotron patterns. These cell parameters strongly differ from the proposed indexation of $\alpha-\mathrm{Rb}_{3} \mathrm{AlF}_{6}{ }^{10} \mathrm{~A}$ subsequent ICDD database search using similar cell parameters, volume tolerance fixed at $10 \%$, and chemistry restrictions (only alkali metals, transition metals, and fluorine) resulted in one compound with similar indexation: $\gamma-\mathrm{K}_{3} \mathrm{AlF}_{6}$ (ICSD 262077). This compound crystallizes in the Fddd space group. The proposed orthorhombic indexation was then tested via a LeBail fit of the SPD pattern, and the obtained good reliability factors $\left(\mathrm{R}_{\mathrm{wp}}=\right.$ $5.48 \%, \mathrm{R}_{\mathrm{p}}=3.31 \%$, and G.O.F. $\left.=0.7\right)$ confirmed that $\alpha$ $\mathrm{Rb}_{3} \mathrm{AlF}_{6}$ appears isostructural to $\gamma-\mathrm{K}_{3} \mathrm{AlF}_{6}$. Moreover, the cell parameters and the space group Fddd of the rubidium cryolite compound was confirmed by an electron diffraction study (Figure 1).

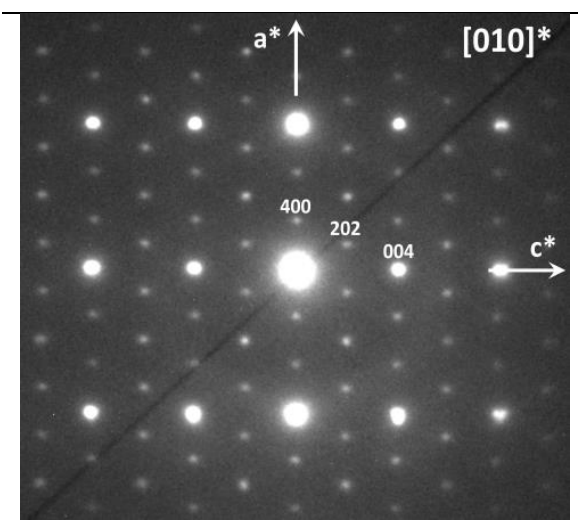

Figure 1. [o10] selected area electron diffraction pattern of $\alpha-\mathrm{Rb}_{3} \mathrm{AlF}_{6}$. Indexed in the $a=37.27 \AA, b=12.45 \AA$ and $c=17.68 \AA$ A cell with a Fddd space group.

In order to precisely determine the structure of $\alpha-\mathrm{Rb}_{3} \mathrm{AlF}_{6}$, a Rietveld refinement of the SPD pattern was performed. The starting model was based on the $\gamma-\mathrm{K}_{3} \mathrm{AlF}_{6}$ structure using the orthorhombic cell parameters previously determined by auto-indexing methods and replacing potassium by rubidium atom. Both cationic and fluorine positions, as well as atomic displacement parameters, were refined ( $\mathrm{Ta}$ ble 1$)$. Good reliability factors were obtained $\left(R_{w p}=6.23 \%\right.$, $\mathrm{R}_{\mathrm{p}}=4.12 \%$ and $\mathrm{GOF}=\mathrm{o} .8$ ). The Rietveld refinement also allowed the identification of a secondary phase of $\mathrm{RbSiO}_{4}$, which quantification was determined as $2.45(5) \mathrm{wt} \%$. This phase is probably a result of a contamination caused by a reaction of $\mathrm{RbF}$ and the ceramic materials (alumino-silicate tube) in the furnace when the synthesis was performed.

The fit of the SPD Rietveld refinement is shown in Figure 2. Atomic coordinates, atomic displacement parameters and $\mathrm{Rb}-\mathrm{F}$ and $\mathrm{Al}-\mathrm{F}$ interatomic distances are summarized in Tables 2 and $\mathrm{S}$.

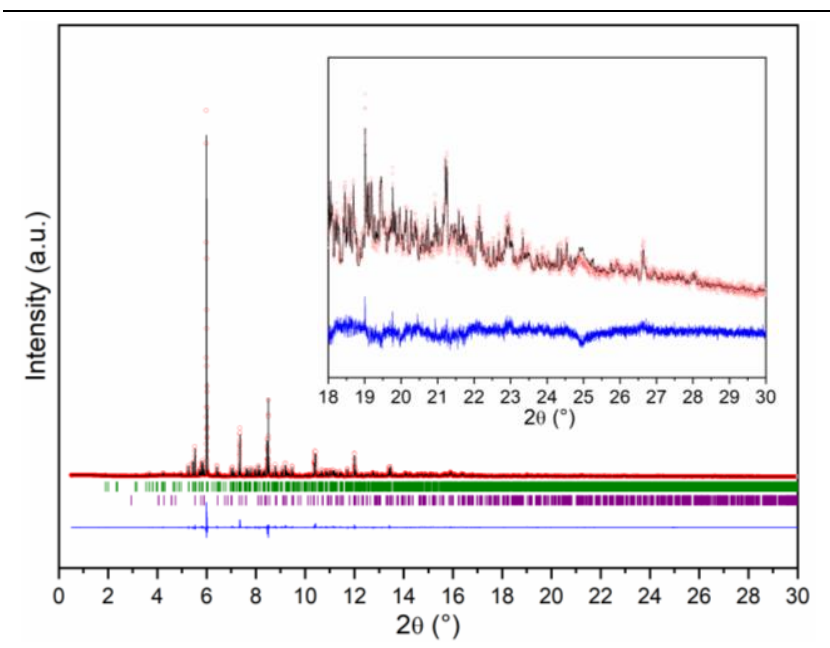

Figure 2. Experimental (red), calculated (black), and difference (blue) SPD Rietveld refinement of $\alpha-\mathrm{Rb}_{3} \mathrm{AlF}_{6}$ (green marks); the Bragg peaks position of the secondary phase $\mathrm{RbSiO}_{4}$ as impurity were visible in purple. An enlargement of the $18-30^{\circ}$ range is embedded.

Table 1. Crystallographic data for the polymorphs of $\mathrm{Rb}_{3} \mathrm{AlF}_{6}$ from XRD Rietveld refinement.

\begin{tabular}{|c|c|c|}
\hline Chemical formula & $\alpha-\mathrm{Rb}_{3} \mathrm{AlF}_{6}$ & $\beta-\mathrm{Rb}_{3} \mathrm{AlF}_{6}$ \\
\hline Source & synchrotron & synchrotron \\
\hline $\begin{array}{l}\text { Formula weight } \\
\left(\mathrm{g} \cdot \mathrm{mol}^{-1}\right)\end{array}$ & 397.4 & 397.4 \\
\hline Temperature $\left({ }^{\circ} \mathrm{C}\right)$ & RT (20) & 600 \\
\hline Wavelength $(\AA ̊)$ & 0.32623 & 0.32623 \\
\hline Crystal system & $\begin{array}{l}\text { Orthorhom- } \\
\text { bic }\end{array}$ & Cubic \\
\hline Space group & Fddd $\left(\mathrm{n}^{\circ} 7 \mathrm{o}\right)$ & $\begin{array}{l}F m- \\
\overline{3} m\left(\mathrm{n}^{\circ} 225\right)\end{array}$ \\
\hline \multirow{4}{*}{$\begin{array}{l}\text { Unit cell dimen- } \\
\text { sions }(\AA)\end{array}$} & $a=37.26491(1)$ & \multirow[t]{4}{*}{$a=8.9930(2)$} \\
\hline & $b \quad=$ & \\
\hline & $12.45405(4)$ & \\
\hline & $c=17.68341(6)$ & \\
\hline Cell volume $\left(\AA^{3}\right)$ & 8206.85 & $727 \cdot 30$ \\
\hline $\mathrm{Z}$ & 48 & 4 \\
\hline d-space range & $0.4-37$ & $0.4-37$ \\
\hline$\chi^{2}$ & 0.8 & 0.89 \\
\hline $\mathrm{R}_{\mathrm{p}}(\%)$ & 4.12 & 4.7 \\
\hline $\mathrm{R}_{\mathrm{wp}}(\%)$ & 6.23 & 7.92 \\
\hline
\end{tabular}

For definition of R-factors see reference 40-41.

Table 2. Atomic coordinates and Atomic Displacement Parameters of $\alpha-\mathrm{Rb}_{3} \mathrm{AlF}_{6}$ determined from Rietveld Refinement of synchrotron powder diffraction data collected at room temperature. 


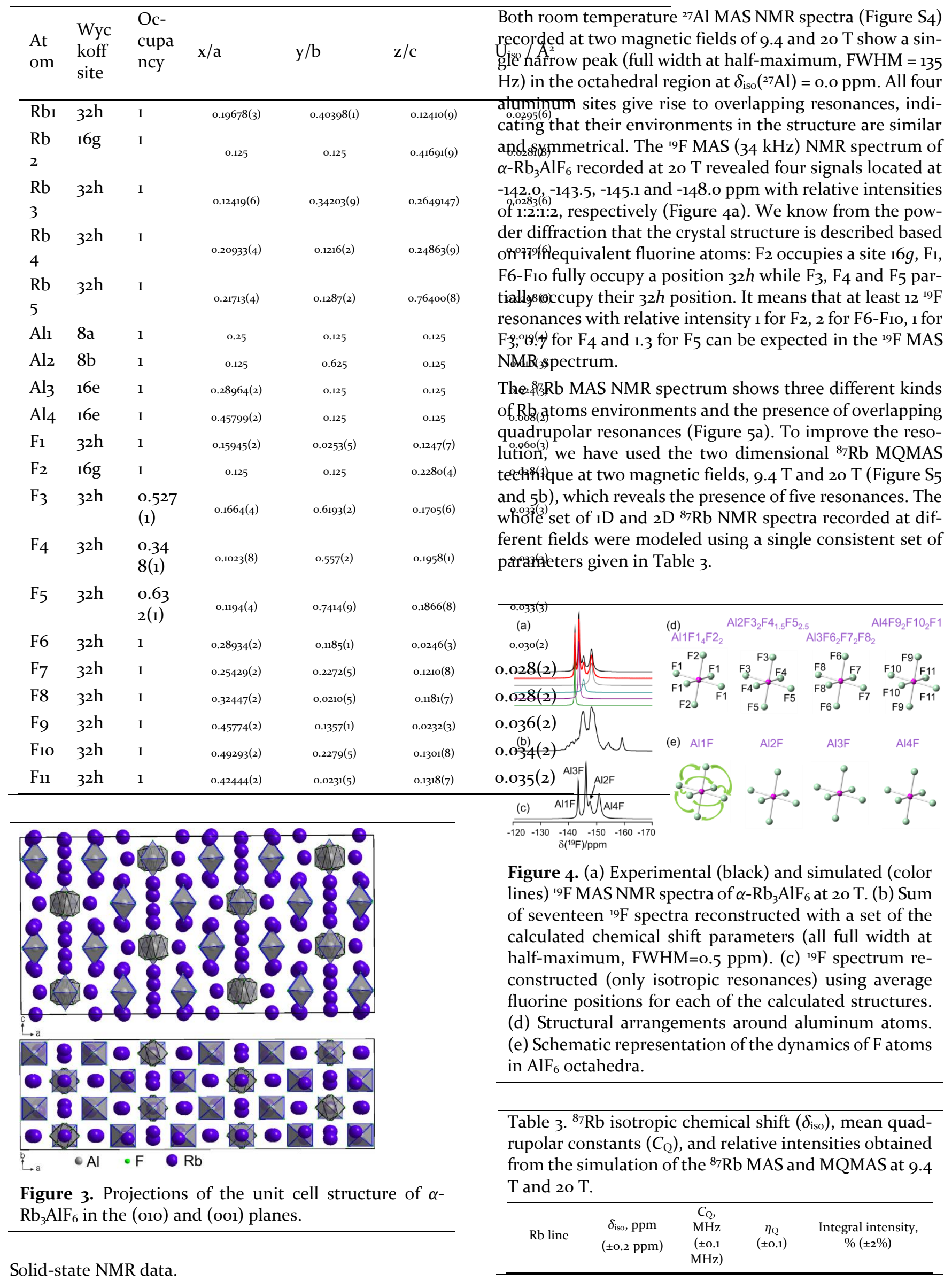




\begin{tabular}{ccccc}
\hline 5 & 44.7 & 5.3 & 0.6 & 18 \\
4 & 42.2 & 6.2 & 0.65 & 17 \\
3 & 18.6 & 5.3 & 0.5 & 30 \\
2 & 14.1 & 3.8 & 0.5 & 12 \\
1 & -22.4 & 2.7 & 0.8 & 23 \\
\hline
\end{tabular}

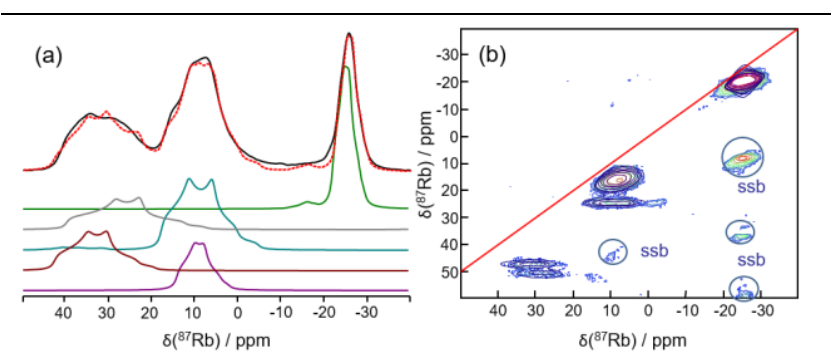

Figure 5. (a) Experimental (black) and simulated (color lines) ${ }^{87} \mathrm{Rb}$ MAS NMR spectra, (b) ${ }^{87} \mathrm{Rb}$ MQ MAS experimental (color lines) NMR spectrum of $\mathrm{Rb}_{3} \mathrm{AlF}_{6}$ at $20 \mathrm{~T}$ and spinning rate of $30 \mathrm{kHz}$ and its simulation (black line) with the parameters presented in Table 3 (ssb stands for spinning side bands).

A description of the potassium environment in $\gamma-\mathrm{K}_{3} \mathrm{AlF}_{6}$ was reported by King et al. ${ }^{8}$ In $\alpha-\mathrm{Rb}_{3} \mathrm{AlF}_{6}$, half of the Rb1 atoms is 7-coordinated while the other half of atoms shows a 6-coordinated octahedral environment. Rb2 atoms are 7coordinated. $\mathrm{Rb}_{3}, \mathrm{Rb}_{4}$, and $\mathrm{Rb}_{5}$ atoms are each surrounded by 10,11 or 12 fluorine atoms, due to partial occupancy of $\mathrm{F}_{3}, \mathrm{~F}_{4}$, and $\mathrm{F}_{5}$ sites. Consequently, six ${ }^{87} \mathrm{Rb}$ resonances with relative intensities of 1 for $1 / 2 \mathrm{Rb}_{1} F_{6}, 1$ for the second $1 / 2$ $\mathrm{Rb}_{1} \mathrm{~F}_{7}, 1$ for $\mathrm{Rb} 2$, and $2 / 2 / 2$ for $\mathrm{Rb}_{3} / \mathrm{Rb}_{4} / \mathrm{Rb}_{5}$ were expected on the ${ }^{87} \mathrm{Rb}$ MAS NMR spectrum. However, only three broad peaks were observed (Figure 5a).

The MQMAS NMR spectrum provides a better resolution. In fact, five resonances, which are overlapped on the $1 \mathrm{D}$ NMR spectrum, are now clearly distinguish (Figure $5 \mathrm{~b}$ ). The resonances are in the range -20 to $40 \mathrm{ppm}$. The only reported ${ }^{87} \mathrm{Rb}$ NMR spectra in literature are that of $\mathrm{RbF}$ and a $\mathrm{RbLaF}_{4}$. Rubidium fluoride adopts a cubic structure with $\mathrm{RbF}_{8}$ coordination (resonance is located at $19.1 \mathrm{ppm}$ ). 35 The structure of $\mathrm{RbLaF}_{4}$ contains a $\mathrm{RbF}_{7}$ edge-tricapped trigonal prism. The rubidium resonance at $51.1 \mathrm{ppm}$ has a quadrupolar broadening with $C_{\mathrm{Q}}$ value of $10.97 \mathrm{MHz}$ and $\eta_{\mathrm{Q}}$ value of $1 .{ }^{36}$ It means that there is no established relationship between the coordination number of the rubidium cation and their chemical shift. In the case of $\mathrm{RbAlF}_{4}$, the rubidium atoms, like in $\mathrm{RbF}$, have eightfold cubic coordination environments. The ${ }^{8} \mathrm{Rb}^{\mathrm{RMR}} \mathrm{RbAlF}_{4}$ spectrum shows a single resonance at $1.8 \mathrm{ppm}$ (see Figure S6). In an attempt to better understand and assign the ${ }^{87} \mathrm{Rb}$ NMR spectrum of $\alpha-\mathrm{Rb}_{3} \mathrm{AlF}_{6}$, we also recorded a ${ }^{8} \mathrm{Rb}-{ }^{19} \mathrm{~F}$ DHMQC HETCOR MAS NMR spectrum (see Figure $S_{7}$ ). The strong overlap of the ${ }^{87} \mathrm{Rb}$ resonances, however, did not allow any further assignment of the resonances.

First-Principles Calculations.

In order to confirm the structure of $\alpha-\mathrm{Rb}_{3} \mathrm{AlF}_{6}$ and to gain a better understanding of the discrepancy regarding the ${ }^{19} \mathrm{~F}$
NMR spectra, a GIPAW calculation of the NMR parameters was performed. Since CASTEP cannot handle partial occupancies of fluorine $\mathrm{F}_{3}, \mathrm{~F}_{4}$ and $\mathrm{F}_{5}$, a set of structures (compatible with the experimental site occupancy factors) were at the beginning generated by a combinatorial approach. ${ }^{37}$ The whole set of combinations of a supercell, which is in this case 213744. This is too big to be able be processed it in one single step. Figure 6a depicts a chart of the electrostatic energies, which are lined up by rising order of all structures. The minimum calculated Coulomb energy $\left(\mathrm{Ec}_{\min }=-1188.6 \mathrm{eV}\right)$ was taken as a base to which the energy values are relative to circa $59 \mathrm{eV}$ (a whole extent of the distribution of the calculated energies). Figure $6 \mathrm{~b}$ is aiming to the 250 lowest-Ec structures, where we hope, the best correlation with the real system, can be found. The initial 10 lowest-Ec and every 20 up to 200 structures were selected for further optimization. The optimization of the geometry of the last three structures (ranked $160^{\text {th }}, 180^{\text {th }}$, and $200^{\text {th }}$ ), was not however reached, even after one week of iterations. It was due to a strong movement of fluorine atoms from the initial positions.

The final outcome is based on 17 structures. All calculated ${ }^{19} \mathrm{~F} \delta_{\text {iso }}$ are shown in Figure $4 \mathrm{~b}$, where the comparison to the experimental MAS NMR spectrum can also be seen. The disapproval between the experimental and calculated data is larger than what is generally considered as a normal for inorganic fluorides. This discrepancy may has arisen either from bad position of atoms in the unit cell, or from dynamic effects that had not been taken in to the GIPAW calculations. Because SPD refinements had not given a clear proof for residual electron density, we inquired the dynamic-reorientation hypothesis. This hypothesis is based on the fact that isolated $\mathrm{AlF}_{6}$ polyhedra in inorganic fluorides can display, even in room temperature, a reorientation (dynamic rotations of the $\mathrm{AlF}_{6}$ octahedra). ${ }^{39}$
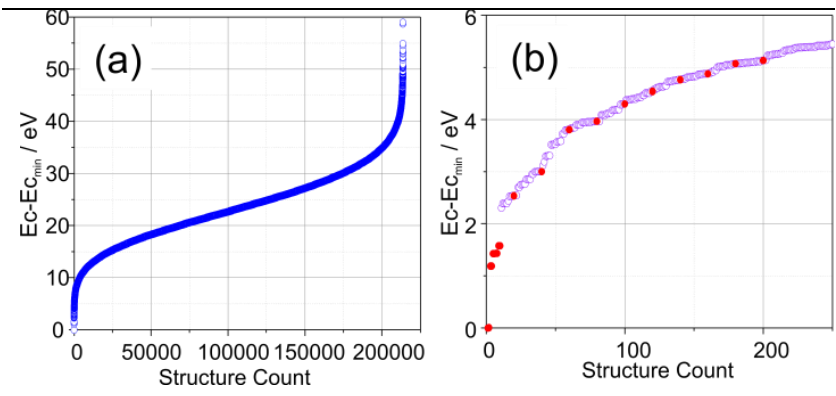

Figure 6. (a) A chart of the electrostatic energies $\left(E_{C}\right)$ of the 213744 distinct structural models lined up by rising order of all structures. (b) Extended view of the 250 structures of lowest $\mathrm{E}_{\mathrm{C}}$. The first 10 lowest- $\mathrm{E}_{\mathrm{C}}$ and every 20-200 structures, shown as red circles, were chosen for further calculations.

By analyzing the $\mathrm{Al}$ environments, one can notice that the four $\mathrm{Al}$ atomic positions have two or three distinct fluorine atoms in their coordination spheres: $\mathrm{Al}_{1} \mathrm{Fl}_{4} \mathrm{~F}_{2}$, $\mathrm{Al}_{2} \mathrm{~F}_{32} \mathrm{~F}_{41.5} \mathrm{~F}_{52.5}, \mathrm{Al}_{3} \mathrm{~F}_{2} \mathrm{~F}_{72} \mathrm{~F}_{2}$ and $\mathrm{Al}_{4} \mathrm{~F}_{92} \mathrm{~F}_{10} \mathrm{~F}_{11}$. Considering fast hoping of the fluorine on each position around one $\mathrm{AlF}_{6}$ octahedron, the ${ }^{19} \mathrm{~F} \delta_{\text {iso }}$ is then the barycenter of the 
individual $\delta_{\text {iso. }}$. We suppose that the fluorine atoms change their positions between the crystallographic sites by flipping. Since motion is not introduced in CASTEP, we can simply average the fluorine positions on each of the calculated structures. The multiplicities of the $\mathrm{Al}_{1}: \mathrm{Al}_{2}: \mathrm{Al}_{3}: \mathrm{Al}_{4}$ sites are 1:1:2:2, and expected integral intensities agree well with the experimental values. The overall good agreement between the reconstructed and experimental ${ }^{19} \mathrm{~F}$ spectrum enables to perform accurate spectral assignment of the NMR resonances with the crystallographic sites. This last result enables validation of i) the structural model and ii) the fast hoping hypothesis occurring at room temperature. To reconstruct the ${ }^{19} \mathrm{~F}$ spectrum, the line widths (FWHM) were used corresponding to the experimental values. Note that the obtained average isotropic magnetic shielding values $\sigma_{\text {iso }}$ for fluorine atoms have very close values $( \pm 0.7$ $\mathrm{ppm}$ ), which allows us to assert that increasing the number of structures used for prediction will not significantly change the final result. Seventeen structures are enough to image the real structure.

The fast motion of fluorine atoms is also responsible for the small $C_{\mathrm{Q}}$ value observed for the ${ }^{27} \mathrm{Al}$ resonances, when the calculated values range 1-8.2 MHz. This motion is also responsible for the uniqueness of all $4 \mathrm{Al}$ resonances. Regarding rubidium atoms, the analysis of the DFT calculations could not be done since each $\mathrm{Rb}$ atom has in its coordination sphere several fluoride ions coming from different $\mathrm{AlF}_{6}$ polyhedra, each one having independent dynamics.

These dynamic rotations of the $\mathrm{AlF}_{6}$ octahedra were observed in $\delta-\mathrm{K}_{3} \mathrm{AlF}_{6}$ phase, and it was supposed that such rotations could be occurring in some of the lower temperature phases as well. ${ }^{8}$ Our data confirms this supposition.

\section{$\beta-\mathrm{Rb}_{3} \mathrm{AlF}_{6}$}

High-Temperature synchrotron powder diffraction data.

In order to track the $\alpha-\mathrm{Rb}_{3} \mathrm{AlF}_{6}$ to $\beta-\mathrm{Rb}_{3} \mathrm{AlF}_{6}$ phase transition, observed by thermal analysis around $350^{\circ} \mathrm{C}$, high-resolution synchrotron powder diffraction diagrams were collected (Figure 7) from room temperature up to $600{ }^{\circ} \mathrm{C}$ (using $100{ }^{\circ} \mathrm{C}$ steps). The phase transformation between 300 ${ }^{\circ} \mathrm{C}$ and $400{ }^{\circ} \mathrm{C}$ was also observed.

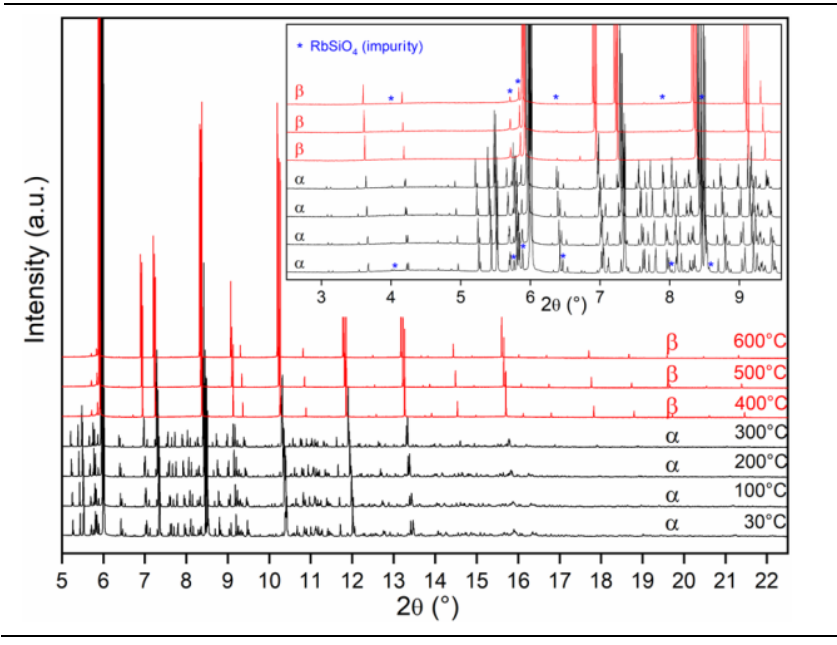

Figure 7. Synchrotron powder diffraction patterns of $\mathrm{Rb}_{3} \mathrm{AlF}_{6}$ recording as a function of temperature upon heating. The diagrams corresponding to low temperature form (orthorhombic Fddd with $a=37.26491(1) \AA$, $b=12.45405(4) \AA$ and $c=17.68341(6) \AA)$ and high temperature form (cubic $F m-\overline{3} m$ with $a=8.9930(2) \AA$ ) are indicated by $\alpha$ and $\beta$ symbols respectively.

The same procedure, as used for the room temperature polymorph, was applied to solve and refine the crystal structure of the high temperature polymorph (data recorded in-situ at $600^{\circ} \mathrm{C}$ ). A cubic unit cell with $a=8.9930(2)$ $\AA$ was determined from auto indexing routines, whereas the most symmetric $F m-\overline{3} m$ space group was found suitable for the high-temperature $\beta$ - $\mathrm{Rb}_{3} \mathrm{AlF}_{6}$ polymorph. An isostructural model could be identified, namely $\delta-\mathrm{K}_{3} \mathrm{AlF}_{6}$ (ICSD 262078). The structure refinement was therefore performed using this structural model as starting point using a $\mathrm{Rb}$ substitution for $\mathrm{K}$ atomic positions and isotropic thermal factors for $\mathrm{Rb}, \mathrm{Al}$ and $\mathrm{F}$. The refinement converged to low $R_{B}$-factor values of (Figure 8$)\left(R_{w p}=7.92 \%, R_{p}=4.70\right.$ $\%$ and $\mathrm{GOF}=0.89$ ). The main results of the Rietveld refinement are reported in Table 4.

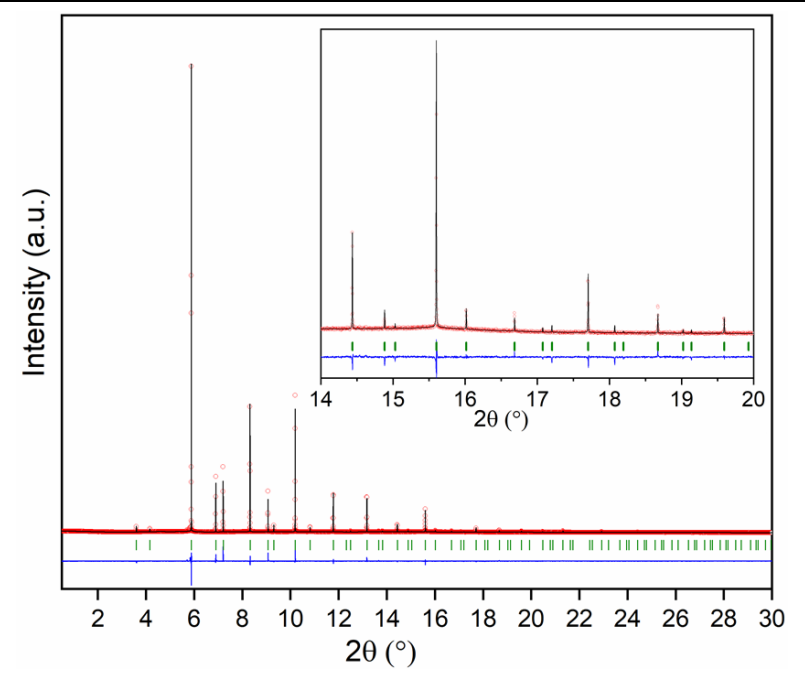

Figure 8. Rietveld refinement of the SPD pattern of $\beta$ $\mathrm{Rb}_{3} \mathrm{AlF}_{6}$ collected at $600{ }^{\circ} \mathrm{C}$. Experimental (red), calculated (black), difference (blue) and Bragg reflections (cubic $F m-\overline{3} m a=8.9930(2) \AA ̊$ ) (green marks) are represented.

Table 4. Atomic coordinates and Atomic Displacement Parameters of $\beta-\mathrm{Rb}_{3} \mathrm{AlF}_{6}$ determined from in-situ Rietveld Refinement of synchrotron powder diffraction data collected at $600{ }^{\circ} \mathrm{C}$.

\begin{tabular}{ccccccc}
\hline $\begin{array}{c}\text { Ato } \\
\mathrm{m}\end{array}$ & $\begin{array}{c}\text { Wyck } \\
\text { off } \\
\text { site }\end{array}$ & $\begin{array}{c}\text { Oc- } \\
\text { cupa } \\
\text { ncy }\end{array}$ & x/a & y/b & z/c & $\mathrm{U}_{\text {iso }} / \AA^{2}$ \\
\hline Rb1 & $8 \mathrm{c}$ & 1 & 0.25 & 0.25 & 0.25 & $0.0676(3)$ \\
$\mathrm{Rb} 2$ & $4 \mathrm{~b}$ & 1 & 0.5 & 0.5 & 0.5 & $\begin{array}{c}0.0685(4 \\
)\end{array}$ \\
\hline
\end{tabular}




\begin{tabular}{ccccccc}
\hline Al1 & $4 \mathrm{a}$ & 1 & $\mathrm{o}$ & $\mathrm{o}$ & $\mathrm{o}$ & $0.0531(1)$ \\
$\mathrm{F} 1$ & $24 \mathrm{e}$ & 1 & 0.2002 & $\mathrm{o}$ & $\mathrm{o}$ & $0.1110(1)$
\end{tabular}

(2)

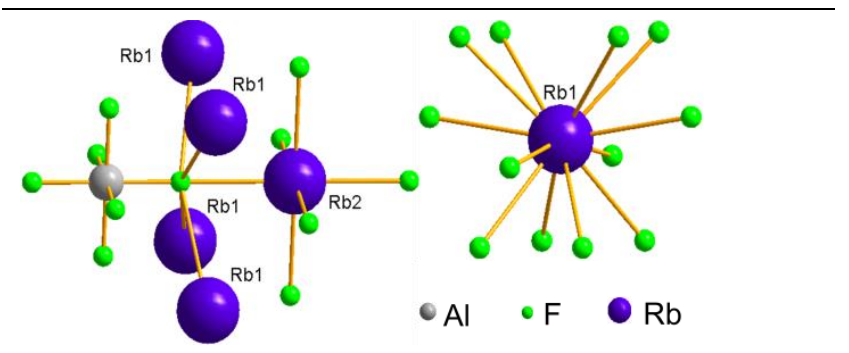

Figure 9. Structural arrangements around aluminum, fluorine, and rubidium atoms.

$\beta-\mathrm{Rb}_{3} \mathrm{AlF}_{6}$ has an ideal cubic structure of a double perovskite with space group $F m-\overline{3} m$. The $\mathrm{AlF}_{6}$ octahedra are centered at the origin and the face centers of the cubic cell. Rubidium atoms adopt an $\mathrm{RbF}_{6}$ and $\mathrm{RbF}_{12}$ coordination (Figure 9).

The fluorine atomic displacement parameter (ADP) is very large $\left(\mathrm{U}_{\text {iso }}=0.111 \AA^{2}\right)$, which might reflect static or dynamic disorder. This large value was previously observed in case of $\delta$-phase of $\mathrm{K}_{3} \mathrm{AlF}_{6}{ }^{8}$ Based on reverse Monte Carlo simulations, the authors ${ }^{8}$ explained the large anisotropy of the fluorine ADPs by significant rotations of $\mathrm{AlF}_{6}$ octahedra. It can be noted that disorder on $\mathrm{F}$ atomic positions was also previously reported in the $\beta$ sodium cryolite. 5

High-Temperature MAS NMR data.

$\beta-\mathrm{Rb}_{3} \mathrm{AlF}_{6}$ : As it was shown previously, the room temperature ${ }^{19} \mathrm{~F}$ MAS NMR spectrum of $\mathrm{Rb}_{3} \mathrm{AlF}_{6}$ ( $\alpha$-phase) has shown four isotropic resonances. At the low MAS frequency $(5 \mathrm{kHz}$, required for the HT measurements) and high field (17.6 T), numerous spinning sidebands are presented due to the chemical shift anisotropy (Figure S8). Therefore, the MATPASS pulse sequence was used. As it was expected, the resolution of the room temperature ${ }^{19} \mathrm{~F}$ MATPASS NMR spectrum recorded at $5 \mathrm{kHz}$ MAS frequency is much lower than at $30 \mathrm{kHz}$, but still the four ${ }^{19} \mathrm{~F}$ resonances can still be distinguished (Figure 10). For ${ }^{87} \mathrm{Rb}$, the $30 \mathrm{kHz}$ MAS and $5 \mathrm{kHz}$ QMATPASS NMR spectra are identical. ${ }^{19} \mathrm{~F}$ MATPASS and ${ }^{87} \mathrm{Rb}$ QMATPASS NMR spectra were recorded in the temperature range $\mathrm{RT}<\mathrm{t} \leq 35^{\circ} \mathrm{C}$ (Figures 10 and 11). For higher temperature, the transverse relaxation time significantly decreased, so that the intensity of the echo signal after three rotor periods was too small to carry out the side band separation. Therefore, in the range $363{ }^{\circ} \mathrm{C}<\mathrm{t}<600{ }^{\circ} \mathrm{C}$, the MAS NMR spectra were recorded using a single pulse excitation. A complete reversibility, without hysteresis of the spectral changes, was observed.

It is worth noting that room temperature MAS NMR measurements were performed without temperature regulation. Due to frictional heating, the real temperatures of the sample were $32{ }^{\circ} \mathrm{C}$ at $5 \mathrm{kHz}$ MAS and $56^{\circ} \mathrm{C}$ at $30 \mathrm{kHz}$.
The ${ }^{19} \mathrm{~F}$ lines were, upon slight heating $\left(90^{\circ} \mathrm{C}\right)$, significantly sharpened, which confirmed the facile motion of the fluoride anions in the structure. A further sharpening of the ${ }^{19} \mathrm{~F}$ resonances (and also small shift) is visible while heating up to the phase transition temperature (Figure 10, left). At the phase transition temperature $\left(35^{\circ} \mathrm{C}\right)$, an additional peak at $-143.7 \mathrm{ppm}$ appears, which is corresponding to the initial formation of the $\beta$-phase. This phase contains a single crystallographic F site. The coexistence of both $\alpha$ - and $\beta$-polymorphs can be seen in the $35^{2-363}{ }^{\circ} \mathrm{C}$ range (Figure 10). The presence of both phases was possible due to a temperature gradient in the body of the sample. One can notice that the ${ }^{19} \mathrm{~F}$ resonance of the $\beta$-phase has spinning sidebands, indicating limited fluorine motion up to $375^{\circ} \mathrm{C}$ (Figure 10, blue spectrum in the right). A fast fluorine motion, above this temperature, can be seen with an absence of spinning sidebands.

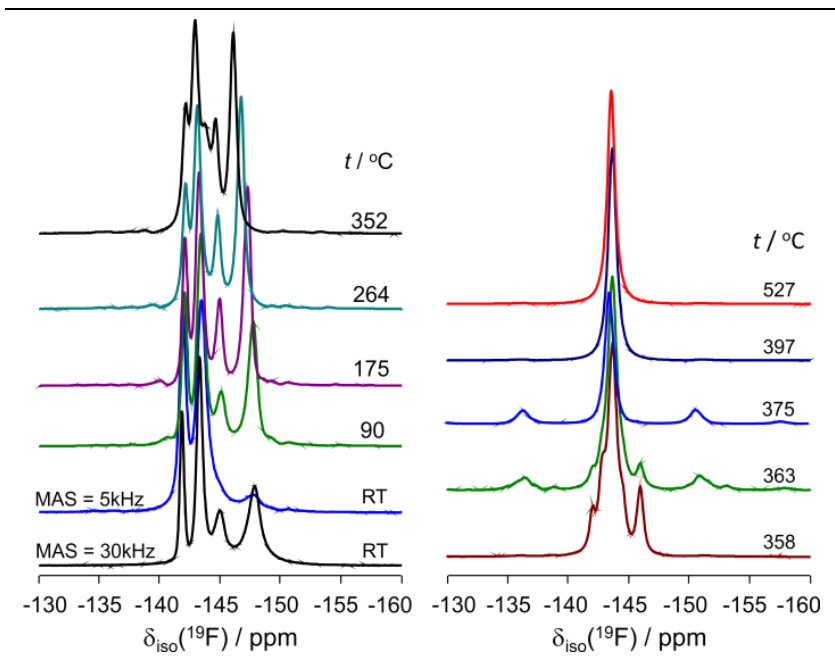

Figure 1o. ${ }^{19} \mathrm{~F}$ NMR spectra of $\mathrm{Rb}_{3} \mathrm{AlF}_{6}$ acquired at $17.6 \mathrm{~T}$ and MAS $5 \mathrm{kHz}$ as a function of temperature: Isotropic slices of MATPASS for $\mathrm{t} \leq 35^{\circ} \mathrm{C}$ and one pulse for $\mathrm{t}>$ $35^{\circ} \mathrm{C}$.

A dynamic exchange between rubidium units could be clearly identified from the temperature dependent line shape evolution in the ${ }^{87} \mathrm{Rb}$ MAS NMR spectra (Figure 11). Above $175{ }^{\circ} \mathrm{C}$, the $2-5$ rubidium resonances broaden and then disappear, indicating the occurrence of dynamic exchange. It should be noted that one line does not change and, therefore, one of the rubidium site does not participate in this exchange. Quantitative analysis of the exchange is hampered by the strong overlap of the 2-5 resonances. Above the phase transition temperature, a new ${ }^{87} \mathrm{Rb}$ resonance appears at $0.7 \mathrm{ppm}$, corresponding to the $\beta$-phase. Up to $363{ }^{\circ} \mathrm{C}$, the coexistence of both phases is confirmed. The phase transition from the room-temperature $\alpha$-phase to the high temperature $\beta$-phase is clearly revealed in the ${ }^{19} \mathrm{~F}$ and ${ }^{87} \mathrm{Rb}$ NMR spectra at $352^{\circ} \mathrm{C}$. This temperature range also matches the transition temperature measured by DSC. 


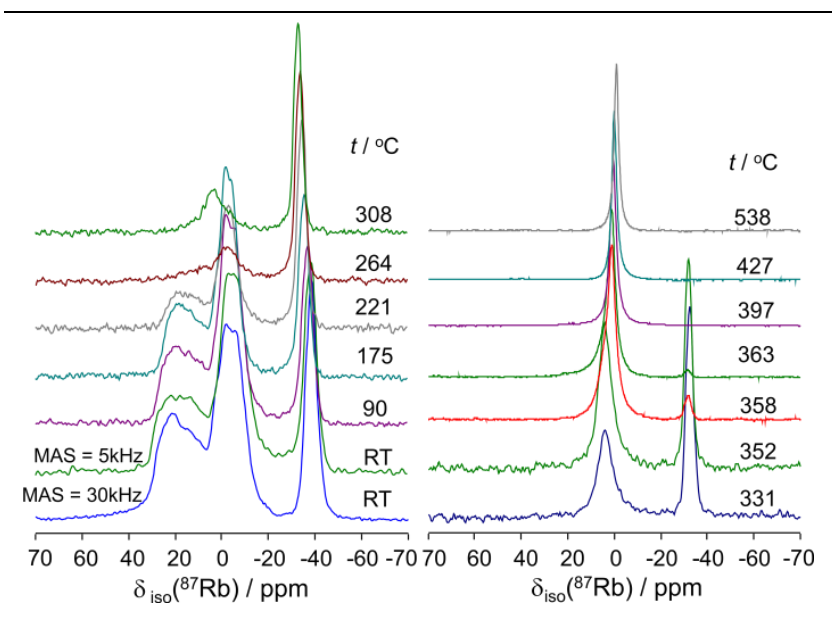

Figure 11. ${ }^{87} \mathrm{Rb}$ NMR spectra of $\mathrm{Rb}_{3} \mathrm{AlF}_{6}$ at $17.6 \mathrm{~T}$ and MAS $5 \mathrm{kHz}$ as a function of temperature: Isotropic slices of QMATPASS for $\mathrm{T} \leq 352^{\circ} \mathrm{C}$ and one pulse for $\mathrm{T}>352^{\circ} \mathrm{C}$.

The ${ }^{19} \mathrm{~F}$ and ${ }^{87} \mathrm{Rb}$ spectra recorded at $397^{\circ} \mathrm{C}$ exhibit an extremely narrow (FWHM $\sim 750 \mathrm{~Hz}$ for ${ }^{87} \mathrm{Rb}$ and $\sim 550 \mathrm{~Hz}$ for $\left.{ }^{19} \mathrm{~F}\right)$ singlet resonance without any spinning sidebands. The rubidium and fluorine signals were simulated by one Gaussian line with a chemical shift at $0.7 \mathrm{ppm}$ and -143.7 ppm at $\mathrm{T}=397^{\circ} \mathrm{C}$, respectively. From this observation and the fact that there are two rubidium sites in the structure, we conclude that the rubidium sites in $\beta-\mathrm{Rb}_{3} \mathrm{AlF}_{6}$ are involved in chemical exchange process. The calculated ${ }^{19} \mathrm{~F}$ chemical shift value is $-153.5 \mathrm{ppm}$ and it is in reasonably good agreement with our experimental result.

$\mathrm{K}_{3} \mathrm{AlF}_{6}$ : Using the heating of the sample in the MAS NMR rotor by a laser beam, the ${ }^{19} \mathrm{~F}$ MAS NMR spectra of all four polymorphs $\left(\alpha \rightarrow \beta 132{ }^{\circ} \mathrm{C} ; \beta \rightarrow \gamma 153{ }^{\circ} \mathrm{C} ; \gamma \rightarrow \delta 310{ }^{\circ} \mathrm{C}\right)$ of $\mathrm{K}_{3} \mathrm{AlF}_{6}$ could be recorded (Figure 12). The room temperature polymorph $\alpha-\mathrm{K}_{3} \mathrm{AlF}_{6}$ adopts the elpasolite structure (ICSD 260574). ${ }^{7}$ It contains $5 \mathrm{Al}$ sites in slightly distorted octahedral environments, 18 potassium crystallographic sites and 30 crystallographically nonequivalent fluorine sites, and consists of symmetrically equivalent layers of the $\mathrm{AlF}_{6}$ units. Every layer contains the octahedra rotated by $\pi / 4$ around the $c$ and $a$ or $b$ axes (non-cooperative octahedral tilting, NCOT). As previously reported, the ${ }^{19} \mathrm{~F}$ MAS NMR spectrum at $60 \mathrm{kHz}$ and $20 \mathrm{~T}$ consists of a broad envelope of signals in the -156 to -160 ppm range and four small signals at $-162,-164.1,-167.3$, and $-168.5 \mathrm{ppm} .{ }^{18}$ It was not possible to make an assignment of lines to $F$ sites. The $\alpha$ phase is stable up to $132^{\circ} \mathrm{C}$ and further transforms into the tetragonal $\beta$-phase (ICSD 262076), which is stable up to $153^{\circ} \mathrm{C}$. The structure of $\beta-\mathrm{K}_{3} \mathrm{AlF}_{6}$ contains seven $\mathrm{F}$ and two $\mathrm{Al}$ crystallographic sites with multiplicities of 8:4:8:8:8:8:8 for $\mathrm{F}$ and $2: 8$ for $\mathrm{Al}$ atoms. Its ${ }^{19} \mathrm{~F}$ MAS NMR spectrum contains an asymmetrically broadened peak with non-Lorenzian lineshape at $-160.1 \mathrm{ppm}$. As in case of $\alpha$ polymorph, the assignment of ${ }^{19} \mathrm{~F}$ signals cannot be provided. In the range $153-306^{\circ} \mathrm{C}$, the orthorhombic $\gamma$ phase (ICSD 262077) exists. The crystalline structure of $\gamma-\mathrm{K}_{3} \mathrm{AlF}_{6}$ contains eleven fluorine sites. The ${ }^{19} \mathrm{~F}$ MAS NMR spectrum, recorded at $160{ }^{\circ} \mathrm{C}$, contains four signals at $-158.2,-159.2,-160.3$ and $-161.9 \mathrm{ppm}$ with relative intensities of $15 / 36 / 17 / 32$, fewer resonances than expected. This again very likely arises from fast dynamics of fluoride ions. The last phase transition occurs above $306{ }^{\circ} \mathrm{C}$. The high temperature cubic $\delta$ phase (ICSD 262078) has double-perovskite structure and it is stable up to the melting temperature of $974{ }^{\circ} \mathrm{C} .39 \delta-\mathrm{K}_{3} \mathrm{AlF}_{6}$ exhibits one kind of fluorine atom, one kind of aluminum atom, and two kinds of potassium atoms. Two potassium atoms are in a $1 / 2$ ratio. The ${ }^{19} \mathrm{~F}$ MAS NMR spectrum measured at $335^{\circ} \mathrm{C}$ exhibits, as expected, a narrow (FWHM $\sim 55 \mathrm{OHz}$ ) singlet resonance at $159.4 \mathrm{ppm}$.

The both high temperature solid-state ${ }^{19} \mathrm{~F}$ NMR spectra of $\gamma-\mathrm{K}_{3} \mathrm{AlF}_{6}$ and $\alpha-\mathrm{Rb}_{3} \mathrm{AlF}_{6}$ contain four lines with the integral intensity ratio of 1:2:1:2. Only one resonance was observed in the flour spectra of $\gamma-\mathrm{K}_{3} \mathrm{AlF}_{6}$ and $\beta-\mathrm{Rb}_{3} \mathrm{AlF}_{6}$. Thus, NMR data obtained for potassium and rubidium cryolites confirms that $\alpha-\mathrm{Rb}_{3} \mathrm{AlF}_{6}$ is isostructural to $\gamma-\mathrm{K}_{3} \mathrm{AlF}_{6}$ and $\beta$ $\mathrm{Rb}_{3} \mathrm{AlF}_{6}$ is isostructural to $\delta$-phase of $\mathrm{K}_{3} \mathrm{AlF}_{6}$. We suppose the existence of low temperature phases of $\mathrm{Rb}_{3} \mathrm{AlF}_{6}$ at temperatures below room temperature, which are isostructural to $\alpha$ - and $\beta-\mathrm{K}_{3} \mathrm{AlF}_{6}$.

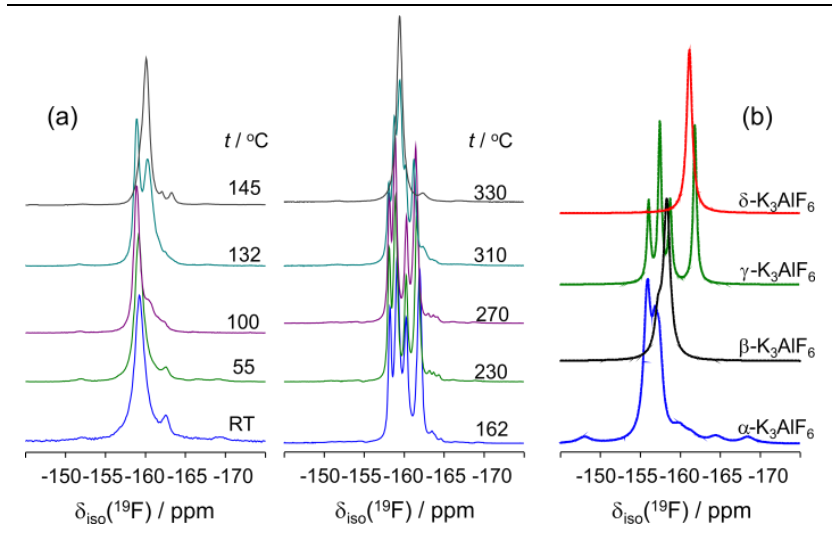

Figure 12. a) Isotropic slices of ${ }^{19} \mathrm{~F}$ NMR MATPASS spectra of $\mathrm{K}_{3} \mathrm{AlF}_{6}$ acquired at $17.6 \mathrm{~T}$ and MAS $5 \mathrm{kHz}$ as a function of temperature. b) Reconstructed ${ }^{19} \mathrm{~F}$ NMR spectra of polymorphs of $\mathrm{K}_{3} \mathrm{AlF}_{6}$ (only isotropic resonances).

Figure $12 \mathrm{~b}$ shows the reconstructed ${ }^{19} \mathrm{~F}$ spectrum of polymorphs of $\mathrm{K}_{3} \mathrm{AlF}_{6}$. The calculation methods are presented in the Supporting Information. Our calculated data show good agreement with ${ }^{19} \mathrm{~F}$ NMR results.

The cryolite mineral, $\mathrm{Na}_{3} \mathrm{AlF}_{6}$, adopts at room temperature $(\alpha \text {-form })^{4}$ a monoclinic structure, which consists of an isolated $\mathrm{AlF}_{6}$ octahedra interconnected by $\mathrm{Na}$ atoms. The $\mathrm{AlF}_{6}$ octahedron is in this structure very regular. Each bond distance and angle does not differ very much from the respective mean value. When we substitute the $\mathrm{Na}^{+}$ions by other alkali cations $\left(\mathrm{K}^{+}, \mathrm{Rb}^{+}\right.$in particular), the cryolite structure will changing, as much as the radius of the alkali metal cation. In these systems, the substitution leads to a lattice distortion due to a rotation of the fraction of the $\mathrm{AlF}_{6}$ octahedral units, which are rotated over a large angle of $\sim 45^{\circ}$. NCOT leads to an increase of the coordination number of the alkali atoms (from 6 up to 12) as it can be seen in our case. Moreover, the substitution also causes the decrease 
of the phase transition temperature, so the highly symmetrical $\alpha-\mathrm{Rb}_{3} \mathrm{AlF}_{6}$ tends to be a stable even at low temperature. The size of the alkali anions is a key factor in the structural relations as well as the physico-chemical behavior of these elpasolite-related fluoride phases.

The following structures exhibiting NCOT have been so far reported: $\mathrm{K}_{3} \mathrm{AlF}_{6},{ }^{7,8} \mathrm{Sr}_{3} \mathrm{WO}_{6},{ }^{14} \mathrm{Rb}_{2} \mathrm{~K}\left(\mathrm{Cr}\right.$ or $\mathrm{Ga}$ ) $\mathrm{F}_{6},{ }^{15}$ and (K or $\mathrm{Rb})_{3} \mathrm{MoO}_{3} \mathrm{~F}_{3}{ }^{16}$ These species contain several NMR active isotopes $\left({ }^{17} \mathrm{O},{ }^{19} \mathrm{~F},{ }^{27} \mathrm{Al},{ }^{69 / 71} \mathrm{Ga},{ }^{87} \mathrm{Sr},{ }^{85} /{ }^{87} \mathrm{Rb}\right)$ that typically allow probing their environment by solid-state NMR spectroscopy. To our knowledge, such an experiment has not yet been however reported. Also DFT calculations of NMR parameters of these compounds are missing in open literature. We think that the major reasons, why this information is still not available, relates to the difficulties to correctly interpret the NMR data. The local dynamics taking places in these structures via NCOT effect, is probably the main reason why it is so difficult to interpret the NMR. The DFT calculations can usually help to explain confusing experimental data. However, the atomic positions with partial occupation can also lead to other problems. This study was the first attempt with a demonstration how solid state NMR methods coupled with computations provide the useful insights into the nature of local dynamics that accompanying the structures with the non-cooperative octahedral tilting effect.

\section{CONCLUSIONS}

Synchrotron powder diffraction, solid-state NMR spectroscopy, electron diffraction, and first-principles calculations have been used as a coupled approach to perform a complete structural characterization of the two polymorphs of rubidium cryolite $\mathrm{Rb}_{3} \mathrm{AlF}_{6}$. The structure of $\alpha-\mathrm{Rb}_{3} \mathrm{AlF}_{6}$ is part of a small family of compounds with non-cooperative octahedral tilting. Variable temperature MAS NMR studies enable the observation of chemical exchange between rubidium sites in $\alpha-\mathrm{Rb}_{3} \mathrm{AlF}_{6}$. High temperature NMR measurements show that $\alpha-\mathrm{Rb}_{3} \mathrm{AlF}_{6}$ is isostructural to $\gamma-\mathrm{K}_{3} \mathrm{AlF}_{6}$ and $\beta-\mathrm{Rb}_{3} \mathrm{AlF}_{6}$ is isostructural to $\delta-\mathrm{K}_{3} \mathrm{AlF}_{6}$. Diffractionbased methods coupled with NMR spectroscopy and DFT calculations was proved as a promising approach to obtain the information about the local dynamics of $\mathrm{AlF}_{6}$ octahedra with the non-cooperative octahedral tilting.

\section{ACKNOWLEDGMENT}

This study was financially supported by CAMPUS FRANCE (PHC STEFANIK project $\left.\mathrm{N}^{\circ} 31799 \mathrm{NM}\right)$, the Slovak bilateral project ( $\mathrm{N}^{\circ}$ SK-FR-2013-0039), and Slovak Grant Agencies (VEGA-2/oo6o/18, APVV-15-0738), and ITMS project (with code 313021To81) supported by Research \& Innovation Operational Programme funded by the ERDF. For DFT calculations, we thank the "Centre de Calcul Scientifique en region Centre" (Orléans, France). We acknowledge the ICMN (Orléans, France) for access to their Transmission Electron Microscope. Financial support from the IR-RMN-THC Fr3050 CNRS for conducting the research is gratefully acknowledged. We thank also Dr. M.Suchomel and Dr. P.Florian for useful discussions.

\section{ASSOCIATED CONTENT}

\section{Supporting Information}

Temperature calibration, X-ray powder diffraction patterns of

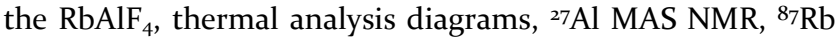
MQMAS, ${ }^{87 R b}$ MAS NMR, 2D D-HMQC MAS NMR, 19F MAS NMR, tables of bond distances (PDF); Crystallographic data (CIF). The Supporting Information is available free of charge on the ACS Publications website.

\section{AUTHOR INFORMATION}

\section{Corresponding Authors}

* Aydar Rakhmatullin, e-mail: rakhmat@cnrs-orleans.fr, tel.: o033-238255512 and František Šimko, e-mail: uachsim@savba.sk, tel.: 00421-2-59410495, fax: 00421-2-59410444

\section{Author Contributions}

A.R. and F.S. conceptualized and planned the project. F.S. performed the thermal analysis experiments. E.V. and M.A. performed structural analysis. A.F. performed high temperature XRD experiments. A.R. conducted of the all NMR experiments with assistance from V.S.K., R.S., F.F., and C.B. Z.N., I.B.P. and M.K. performed the synthesis experiments. A.R., K.O., and C.M. carried out the CASTEP calculations. The manuscript was written with contribution from all co-authors.

Notes

The authors declare no competing financial interest.

\section{REFERENCES}

(1) Fellner, P.; Haarberg, G. M.; Híveš, J.; Kvande, H.; Sterten,

A.; Thonstad, J. Aluminium Electrolysis: Fundamentals of the Hall-

Héroult Process; Beuth Verlag GmbH, 2001.

(2) L. Holm, J.; Jenssen, B.; Sletten, J.; H. Nielsen, P.; A. Lind-

berg, A.; Jansen, G.; Lamm, B.; Samuelsson, B. A Note on the Polymorphy and Structure of $\mathrm{Li}_{3} \mathrm{AlF}_{6}$. Acta Chemica Scandinavica 1969, 23, 1065-1068.

(3) Garton, G.; Wanklyn, B. M. Polymorphism in $\mathrm{Li}_{3} \mathrm{AlF}_{6}$. Journal of Inorganic and Nuclear Chemistry 1965, 27, 2466-2469.

(4) Yang, H.; Ghose, S.; Hatch, D. M. J. P.; Minerals, C. o. Ferroelastic phase transition in cryolite, $\mathrm{Na}_{3} \mathrm{AlF}_{6}$, a mixed fluoride perovskite: High temperature single crystal X-ray diffraction study and symmetry analysis of the transition mechanism. Physics and chemistry of Minerals 1993, 19, 528-544.

(5) Smrčok, L.; Kucharík, M.; Tovar, M.; Žižak, I. High temperature powder diffraction and solid state DFT study of $\beta$-cryolite ( $\left.\mathrm{Na}_{3} \mathrm{AlF}_{6}\right)$. Crystal Research and Technology 2009, 44, 834-840. 
(6) Bučko, T.; Šimko, F. On the structure of crystalline and molten cryolite: Insights from the ab initio molecular dynamics in NpT ensemble. The Journal of Chemical Physics 2016, 144, 064502-13.

(7) Abakumov, A. M.; King, G.; Laurinavichute, V. K.; Rozova, M. G.; Woodward, P. M.; Antipov, E. V. The Crystal Structure of $\alpha-\mathrm{K}_{3} \mathrm{AlF}_{6}$ : Elpasolites and Double Perovskites with Broken CornerSharing Connectivity of the Octahedral Framework. Inorganic Chemistry 2009, 48, 9336-9344.

(8) King, G.; Abakumov, A. M.; Woodward, P. M.; Llobet, A.; Tsirlin, A. A.; Batuk, D.; Antipov, E. V. The High-Temperature Polymorphs of $\mathrm{K}_{3} \mathrm{AlF}_{6}$. Inorganic Chemistry 2011, 50, 7792-7801.

(9) Holm, J. Phase Transitions and Structure of the High-Temperature Phases of some Compounds of the Cryolite Family. Acta Chemica Scandinavica 1965, 19, 261-263.

(10) Chen, R.; Zhang, Q. Phase relations in the system $\mathrm{AlF}_{3}-\mathrm{RbF}$. Thermochimica Acta 1997, 297, 125-129.

(11) Song, E.; Wang, J.; Shi, J.; Deng, T.; Ye, S.; Peng, M.; Wang, J.; Wondraczek, L.; Zhang, Q. Highly Efficient and Thermally Stable $\mathrm{K}_{3} \mathrm{AlF}_{6}: \mathrm{Mn}^{4+}$ as a Red Phosphor for Ultra-High-Performance Warm White Light-Emitting Diodes. ACS Applied Materials $\mathcal{E}$ Interfaces 2017, 9, 8805-8812.

(12) Yang, P.; Doty, F. P.; Rodriguez, M. A.; Sanchez, M. R.; Zhou, X.; Shah, K. S. The Synthesis and Structures of Elpasolite Halide Scintillators. MRS Proceedings 2009, 1164, L1111-1105.

(13) van Eijk, C. W. E. Inorganic Scintillators for Thermal Neutron Detection. IEEE Transactions on Nuclear Science 2012, 59, $2242-2247$

(14) King, G.; Abakumov, A. M.; Hadermann, J.; Alekseeva, A. M.; Rozova, M. G.; Perkisas, T.; Woodward, P. M.; Van Tendeloo, G.; Antipov, E. V. Crystal Structure and Phase Transitions in $\mathrm{Sr}_{3} \mathrm{WO}_{6}$. Inorganic Chemistry 2010, 49, 6058-6065.

(15) Javier Zúñiga, F.; Tressaud, A.; Darriet, J. The low-temperature form of $\mathrm{Rb}_{2} \mathrm{KCrF}_{6}$ and $\mathrm{Rb}_{2} \mathrm{KGaF}_{6}$ : The first example of an elpasolite-derived structure with pentagonal bipyramid in the Bsublattice. Journal of Solid State Chemistry 20o6, 179, 3607-3614.

(16) Fry, A. M.; Woodward, P. M. Structures of $\alpha-\mathrm{K}_{3} \mathrm{MoO}_{3} \mathrm{~F}_{3}$ and $\alpha-\mathrm{Rb}_{3} \mathrm{MoO}_{3} \mathrm{~F}_{3}$ : Ferroelectricity from Anion Ordering and Noncooperative Octahedral Tilting. Crystal Growth E Design 2013, 13, 5404-5410.

(17) Zhou, X. W.; Doty, F. P.; Yang, P. In SPIE Optical Engineering + Applications; Doty, F. P., Barber, H. B., Roehrig, H., Schirato, R. C., Eds.; SPIE: San Diego, California, United States, 2010; Vol. 7806, p. 7806 oE.

(18) Šimko, F.; Rakhmatullin, A.; Florian, P.; Kontrík, M.; Korenko, M.; Netriová, Z.; Danielik, V.; Bessada, C. (Oxo)(Fluoro)Aluminates in $\mathrm{KF}-\mathrm{Al}_{2} \mathrm{O}_{3}$ System: Thermal Stability and Structural Correlation. Inorganic Chemistry 2017, 56, 13349-13359.

(19) Šimko, F.; Rakhmatullin, A.; Véron, E.; Allix, M.; Florian, P.; Kontrík, M.; Netriová, Z.; Korenko, M.; Kavečanský, V.; Bessada, C. Oxo- and Oxofluoroaluminates in the $\mathrm{RbF}-\mathrm{Al}_{2} \mathrm{O}_{3}$ System: Synthesis and Structural Characterization. Inorganic Chemistry 2018, 57, 13702-13712.

(2o) Daněk, V.; Čekovský, R. Phase Transitions and Structure of the High-Temperature phases of some Compounds of the Cryolite Family. Chemical Papers 1992, 46, 161-166.

(21) Trebosc, J.; Hu, B.; Amoureux, J. P.; Gan, Z. Through-space R3-HETCOR experiments between spin-1/2 and half-integer quadrupolar nuclei in solid-state NMR. Journal of Magnetic Resonance 2007, 186, 220-227.

(22) Gan, Z. ${ }^{13} \mathrm{C} /{ }^{14} \mathrm{~N}$ heteronuclear multiple-quantum correlation with rotary resonance and REDOR dipolar recoupling. Journal of Magnetic Resonance 2007, 184, 39-43.

(23) Amoureux, J.-P.; Fernandez, C.; Steuernagel, S. ZFiltering in MQMAS NMR. Journal of Magnetic Resonance, Series A 1996, $123,116-118$.

(24) States, D. J.; Haberkorn, R. A.; Ruben, D. J. A two-dimensional nuclear Overhauser experiment with pure absorption 
phase in four quadrants. Journal of Magnetic Resonance 1982, 48, 286-292.

(25) Hung, I.; Gan, Z. On the magic-angle turning and phaseadjusted spinning sidebands experiments. Journal of Magnetic Resonance 2010, 204, 150-154.

(26) Hung, I.; Gan, Z. A magic-angle turning NMR experiment for separating spinning sidebands of half-integer quadrupolar nuclei. Chemical Physics Letters 2o10, 496, 162-166.

(27) Ivchenko, N.; Hughes, C. E.; Levitt, M. H. Application of cogwheel phase cycling to sideband manipulation experiments in solid-state NMR. Journal of Magnetic Resonance 2003, 164 286-293.

(28) Massiot, D.; Fayon, F.; Capron, M.; King, I.; Le Calvé, S.; Alonso, B.; Durand, J.-O.; Bujoli, B.; Gan, Z.; Hoatson, G. Modelling one- and two-dimensional solid-state NMR spectra. Magnetic Resonance in Chemistry 2002, 40, 70-76.

(29) Lityagina, L. M.; Kabalkina, S. S.; Varfolomeev, M. B.; Losev, V. G. $\mathrm{Na}_{2} \mathrm{SiF}_{6}$ Polymorphism Under Pressure. Zhurnal Neorganicheskoi Khimii 1988, 33, 514-517.

(30) Wu, J.; Kim, N.; Stebbins, J. F. Temperature calibration for high-temperature MAS NMR to $913 \mathrm{~K}:{ }^{6} \mathrm{Cu}$ MAS NMR of $\mathrm{CuBr}$ and $\mathrm{CuI}$, and ${ }^{23} \mathrm{Na} \mathrm{MAS} N \mathrm{NMR}$ of $\mathrm{NaNbO}_{3}$. Solid State Nuclear Magnetic Resonance 2011, 40, 45-50.

(31) Shakhovoy, R. A.; Rakhmatullin, A.; Deschamps, M.; SarouKanian, V.; Bessada, C. Nuclear magnetic resonance study of sulfate reorientations in $\mathrm{LiNaSO}_{4}$. Journal of Physics: Condensed Matter 2016, 28, 176003.

(32) Venkatachalam, S.; Schröder, C.; Wegner, S.; van Wüllen, L. The structure of a borosilicate and phosphosilicate glasses and its evolution at temperatures above the glass transition temperature: lessons from in situ MAS NMR. Physics and Chemistry of Glasses - European Journal of Glass Science and Technology Part B 2014, 55, 280-287.
(33) Sadoc, A.; Biswal, M.; Body, M.; Legein, C.; Boucher, F.; Massiot, D.; Fayon, F. NMR parameters in column 13 metal fluoride compounds $\left(\mathrm{AlF}_{3}, \mathrm{GaF}_{3}, \mathrm{InF}_{3}\right.$ and $\left.\mathrm{TlF}_{3}\right)$ from first principle calculations. Solid State Nuclear Magnetic Resonance 2014, 59-6o, $1-7$.

(34) Grjotheim, K.; Krohn, C.; Malinovský, M.; Matiašovský, K.; Thonstad, J. Aluminium Electrolysis-Fundamentals of the HallHeroult Process, Verlag, Dusseldorf, Germany, 1982.

(35) Rees, G. J.; Day, S. P.; Lari, A.; Howes, A. P.; Iuga, D.; Pitak, M. B.; Coles, S. J.; Threlfall, T. L.; Light, M. E.; Smith, M. E.; Quigley, D.; Wallis, J. D.; Hanna, J. V. A multinuclear solid state NMR, density functional theory and X-Ray diffraction study of hydrogen bonding in Group I hydrogen dibenzoates. CrystEngComm 2013, 15, 8823-8839.

(36) Rollet, A.-L.; Allix, M.; Veron, E.; Deschamps, M.; Montouillout, V.; Suchomel, M. R.; Suard, E.; Barre, M.; Ocaña, M.; Sadoc, A.; Boucher, F.; Bessada, C.; Massiot, D.; Fayon, F. Synthesis and Structure Resolution of $\mathrm{RbLaF}_{4}$. Inorganic Chemistry 2012, $51,2272-2282$.

(37) Okhotnikov, K.; Charpentier, T.; Cadars, S. Supercell program: a combinatorial structure-generation approach for the local-level modeling of atomic substitutions and partial occupancies in crystals. Journal of Cheminformatics 2016, 8, 17-25.

(38) Kotecha, M.; Chaudhuri, S.; Grey, C. P.; Frydman, L. Dynamic Effects in MAS and MQMAS NMR Spectra of Half-Integer Quadrupolar Nuclei: Calculations and an Application to the Double Perovskite Cryolite. Journal of the American Chemical Society 2005, 127, 16701-16712.

(39) Holm, J. L. Phase Transitions and Structure of the HighTemperature phases of some Compounds of the Cryolite Family. Acta Chemica Scandinavica 1965, 19, 261-262.

(40) Boultif, A.; Louer, D. Indexing of powder diffraction patterns for low-symmetry lattices by the successive dichotomy method. Journal of Applied Crystallography 1991, 24, 987-993. 
(41) Werner, P.-E. Trial-and-error computer methods for the indexing of unknown powder patterns. Zeitschrift für Kristallographie 1964, 120, 375-387. 
Table of Contents Synopsis and Graphic

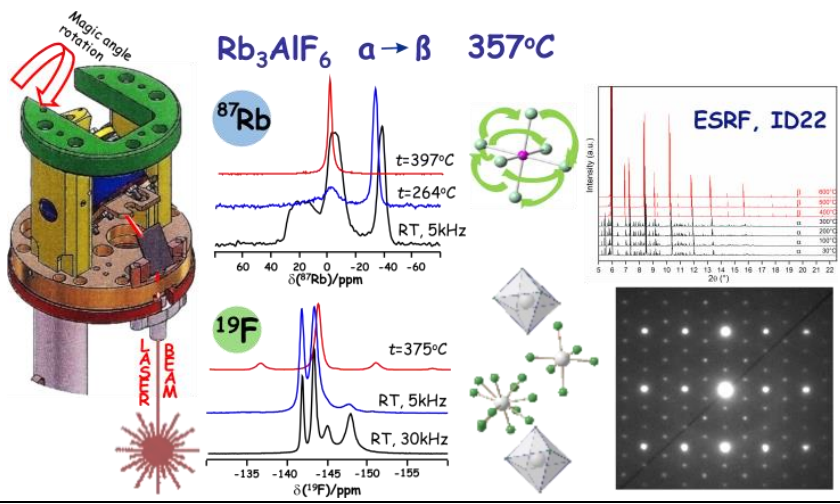

\section{Synopsis:}

Insight into the detailed structure of two polymorphs of the rubidium cryolite $\mathrm{Rb}_{3} \mathrm{AlF}_{6}$ with noncooperative octahedral tilting was obtained by using a combination of synchrotron powder diffraction, multinuclear high temperature solid-state NMR spectroscopy, electron diffraction, and first-principles calculations.

Dynamic processes such as chemical exchange of rubidium sites and rotations of $\mathrm{AlF}_{6}$ octahedra are observed and discussed. 